DOI https://doi.org/10.18551/rjoas.2018-11.24

\title{
EMPOWERMENT PROGRAM THROUGH INCREASING CAPACITY OF ECONOMIC INSTITUTION IN MAGELANG REGENCY OF INDONESIA
}

\author{
Moordiani Roostian* \\ Master Program of Agribusiness, Faculty of Animal and Agricultural Sciences, \\ University of Diponegoro, Indonesia \\ Sumekar Wulan, Gayatri Siwi \\ Faculty of Animal and Agricultural Sciences, University of Diponegoro, Indonesia \\ *E-mail: rose tean@yahoo.com
}

\begin{abstract}
The poverty alleviation strategy through farmer's empowerment increases farmer's institutional capacity, for example, in Indonesia government put a lot of effort to transform a farmer's group (Gabungan Kelompok Tani or gapoktan) into Kelembagaan Ekonomi Petani (KEP) or farmer's economic institution. The objective of the research was to analyze the effect of KEP towards empowerment program among Indonesian farmers. Survey was used in this research. Path analysis was used to analyze the data. KEP had significantly affects into empowerment program. Based on the result, the effect of KEP still needs to be increased through the increasing of institutional capacity as well as more training need to be provided by government. The transforming of farmer's institution into KEP is needed to increase institution independency to become more business oriented. The supervision from government staff is needed, in order to improve farmer's welfare.
\end{abstract}

\section{KEY WORDS}

Farmer, empowerment, empowering farmer, strengthening economic institution.

Poverty alleviation is one of the priorities of national development, including the agricultural sector. Some of the problems faced by farmers include access to capital, technology, marketing and lack of support in farmer's institution (Nuswantara dan Pramonosidhi, 2014). One of the efforts to alleviate poverty can be done by empowering farmers through improve capacity of farmer institutions so that activities in a farmer group can be more effective and efficient. Empowerment strategies through farmer groups will have an impact on increasing their income (Desiana and Atik, 2017).

Farmer's empowerment is an effort to enable and to make farmers independent or help farmers to be able to help to solve their problem (Mardikanto, 2009). Empowering farmer can be done in several ways, such as institutional capacity in farmer group. Indonesian government supports transformation a farmers group or Gapoktan to become more independent in order to enhance institutional capacity. KEP is a farmer economic institution that it carrying out activities which is developed by, from and for farmers to improve economic scale and farming efficiency (Ministry of Agriculture, 2016).

Rural Agribusiness Development (Pengembangan Usaha Agribisnis Pedesaan or PUAP) is an Indonesian government program to facilitate capital assistance for farmers at village level which is giving donation through the farmers group association (Gapoktan) in the form of grant equal to Rp 100.000.000 (one hundred million rupiah). PUAP is a strategic program from the Ministry of Agriculture in order to reduce poverty and unemployment in rural areas (Junaedi, 2013). Capital strengthening is intended to develop agribusiness activities for Gapoktan according local resources and farmer's problem. However, KEP is faced with several problems, such as the weak management of organization and business, it has not yet been oriented on productive business and no legal force, low bargaining position and low accessibility to information, technology, financing and the market (Ministry of Agriculture, 2016). 
Transformation of farmer group into KEP is needed to change farming orientation into business and increase economic scale and efficiency business along with improving bargaining position. Increased capacity of KEP was directed to form cooperatives or other business entities in accordance with the needs, culture and potential condition along with social economic of local people (Ministry of Agriculture, 2016).

This research was focused on KEP program and implementation of PUAP in Magelang Regency. The purpose of this research was to determine the effect of KEP on farmers empowerment in Magelang Regency. The benefits expected from this research were to provide recommendation on how to strengthening and developing institutional farmers into independent farmers economic institutions as well as providing information for the government in making policies related to the KEP and PUAP program hence it can give benefit to the national development.

\section{METHODS OF RESEARCH}

The research was done in Magelang Regency with considerations most of farmer groups in Magelang Regency were able to develop into KEP and Magelang Regency got an award for best KEP program in Central Java Province. There are 1.946 farmers got benefit from KEP program. Probability technique sampling was used to select the respondents. There were 195 respondents were selected in this research.

Independent variables from the effectiveness KEP were group objective achievement, group function and role, group innovativeness and group sustainability. The dependent variable are farmer's empowerement with capital access, information, and the farmer's income. Path analysis was used to analyze the data as well as to analyze the inherent causal relationship between some exogenous and endogenous variables, and to test the intervening variables (Haryono and Wardoyo, 2012).

\section{RESULTS AND DISCUSSION}

General Description of Location. Magelang Regency located in the border of Yogyakarta Province. It is located north of Temanggung Regency; east: part of Semarang Regency and Boyolali Regency, south of Purworejo Regency; west of Temanggung Regency and Wonosobo Regency. The total area of Magelang Regency is $1,085.73 \mathrm{~km} 2$ and divided into 21 districts and 372 villages. 86,405 ha was used for agricultural land or $79.58 \%$ of the area, while 22,168 ha or $20.42 \%$ was used non-agricultural land. 36,855 ha was used for paddy field and the dry land is covering 49,550 ha for food crops, horticulture, plantations and forestry (BPS Magelang Regency, 2017).

There were 271 Gapoktan that have received PUAP funding since 2008. There were many activities developed by Gapoktan such as saving and loan. Moreover, there were 11 Gapoktan which transformed into cooperatives and have been registered by the government (BKPP Magelang Regency, 2016).

Characteristics of Respondents. One important element in agricultural development is farmers as human resources who participate in development program to improve their welfare (Suswono, 2014). Empowerment will succeed if there is participation from all community.

The number of male respondent were higher than female respondents, It is indicating that males were still dominant in farming activities, and have right to joining farmers institutions. Females or the house wives were involved in a number of activities, especially harvest, taking care of the children as well as the house and have a dominant role in decision making related with household accounting. The decision-making process between male and female is generally influenced by the dominance of involvement at each stage of the farming system. Male and normally the head of the household had an access and control over resources, including access and control over land resources which refers to the value of male and access to several sources of capital. (Hutajulu, 2015). 
Respondents are officers and members of farmers group. According to Hariardi (2011) there are 3 types of members in the group, namely officers, active members and ordinary members or less active members. Farmers would check and observe what was the main goals of an organization, and that are the reason someone is being involved or not in group activities, if the group can support someone to get what they want and that needs are met.

Based on age,most respondents were in productive-age. It has a great potential to develop a farmer group into a more independent institution. According to Mardikanto (2009) age is related to the adoption of technological innovations. The older a person is, the longer he or she will adopt technological innovations and they only run a farm in a traditional way based on their habits.

Table 1 - Number and Percentage of Respondents Based on Respondent Characteristics

\begin{tabular}{|c|c|c|c|c|c|c|c|}
\hline Characteristic & Criteria & $\begin{array}{l}\text { Number } \\
\text { (People) }\end{array}$ & $\%$ & Characteristic & Criteria & $\begin{array}{l}\text { Number } \\
\text { (People) }\end{array}$ & $\%$ \\
\hline $\begin{array}{l}\text { Gender } \\
\text { Status in KEP }\end{array}$ & $\begin{array}{l}\text { Male } \\
\text { Female } \\
\text { Officers } \\
\text { Members }\end{array}$ & $\begin{array}{l}106 \\
89 \\
27 \\
168\end{array}$ & $\begin{array}{l}54,4 \\
45,6 \\
13,8 \\
86,2\end{array}$ & \multirow{8}{*}{$\begin{array}{l}\text { Duration of } \\
\text { membership } \\
\text { Type of Farming }\end{array}$} & $\begin{array}{l}1-3 \text { year }(\mathrm{s}) \\
4-6 \text { years } \\
>6 \text { years } \\
\text { Horticulture }\end{array}$ & $\begin{array}{l}68 \\
72 \\
55 \\
113\end{array}$ & $\begin{array}{l}34,9 \\
36,9 \\
28,2 \\
57,95\end{array}$ \\
\hline Age & $\leq 35$ & 62 & 31,8 & & $\begin{array}{l}\text { Horticulture - } \\
\text { Livestock }\end{array}$ & 26 & 13,33 \\
\hline \multirow{6}{*}{$\begin{array}{l}\text { Level of } \\
\text { Education }\end{array}$} & \multirow{6}{*}{$\begin{array}{l}35 \text { - } 65 \\
\geq 65 \\
\text { Bachelor's } \\
\text { Degree } \\
\text { Senior High } \\
\text { School } \\
\text { Junior High } \\
\text { School } \\
\text { Elementary } \\
\text { School } \\
\text { No School }\end{array}$} & $\begin{array}{l}125 \\
8\end{array}$ & $\begin{array}{l}64,1 \\
4,1\end{array}$ & & $\begin{array}{l}\text { Crops } \\
\text { Horticulture - Crops }\end{array}$ & $\begin{array}{l}20 \\
19\end{array}$ & $\begin{array}{l}10,26 \\
9,74\end{array}$ \\
\hline & & 20 & 10,3 & & $\begin{array}{l}\text { Processed } \\
\text { Agricultural Products }\end{array}$ & 11 & 5,64 \\
\hline & & 76 & 39 & & $\begin{array}{l}\text { Horticulture - } \\
\text { Tobacco }\end{array}$ & 4 & 2,05 \\
\hline & & 54 & 27,7 & & Tobacco & 1 & 0,51 \\
\hline & & 43 & 22,1 & & Fishery & 1 & 0,51 \\
\hline & & 2 & 1 & & & & \\
\hline
\end{tabular}

Source: Primary Data 2017.

Based on the level of education, $50.8 \%$ of respondents had a 9-year basic education level or equivalent to a junior high school, while $49.2 \%$ had a high education (undergraduate). A level of education will influence his/her knowledge, as a factor forming individual behavior in the community (Syahyuti, 2011). Level of knowledge will influence decision making (Van den Ban, 1999). This will certainly affect the increase of farmers' income.

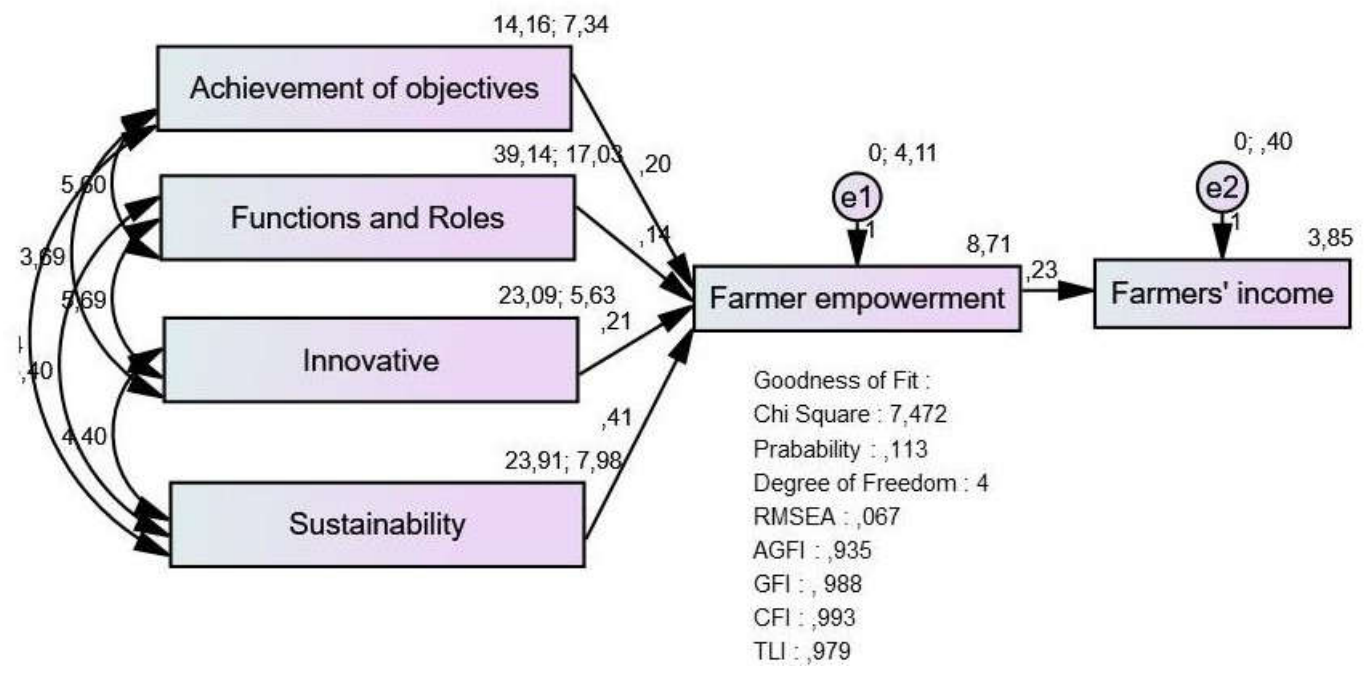

Figure 1 - Relationship between KEP Effect with Empowerment and Income of Farmers in Magelang Regency 
The research location consisted of 7 districts located in the highlands of Magelang Regency. It shows $57.95 \%$ of respondents cultivated horticultural commodities including salak, various chili and vegetables. The respondent tries to cultivate a more profitable commodity so it can meet the needs of his/her family. According to Mardani et al (2017) farming activities have a purpose to increase productivity so that profits become higher.

Effect of Farmers Economy Institution. Based on the results of the path analysis, the exogenous variables are factors that influence the effect of Farmers Economy Institution (KEP). It is covering variables of the achievement group objectives, group roles and functions, group innovativeness. Group sustainability towards farmers' empowerment covering variables of access to capital and access to information. It is illustrated as follows:

The equation from Figure 1 about the relationship between KEP effect with empowerment and income of farmers in Magelang Regency is as follows:

$$
Y=0,20 X_{1}+0,14 X_{2}+0,21 X_{3}+0,41 X_{4}+4,11
$$

The constant value of the equation is 4.11. It proved that the hypothesis is accepted where there is influence of the effectiveness of KEP on the farmers's empowerment in Magelang Regency.

Table 1 - Coefficient of Exogenous Variable towards Endogenous Variable

\begin{tabular}{llllllll}
\hline & & & Estimate & S.E. & C.R. & P & Lable \\
\hline Empowerment & $<---$ & Objective and Achievement & 0,199 & 0,069 & 2,863 & 0,004 & par_1 \\
Empowerment & $<---$ & Function and Role & 0,141 & 0,046 & 3,061 & 0,002 & par_2 \\
Empowerment & $<---$ & Innovativeness & 0,212 & 0,09 & 2,346 & 0,019 & par_3 \\
Empowerment & $<---$ & Sustainability & 0,407 & 0,073 & 5,592 & $* * *$ & par_4 \\
Income & $<---$ & Empowerment & 0,226 & 0,015 & 15,322 & ${ }^{* * *}$ & par_5 \\
\hline
\end{tabular}

Source: Primary Data Analysis.

According to the results of path analysis, it shows that the effect of KEP (X variables) has a real positive effect towards farmer's empowerment ( $Y$ variables). The result shown that the value $p<0.01$ and the regression coefficient value is positive. A positive effect is interpreted when every variable of institutional effect increases, then the empowerment of farmers' experiences will be increased.

The transformation a farmer group into KEP had been supported by Indonesian government in order to provide services and training, business development and enhance participation in the group. Group objectives that are clearly documented will make it easier for officers and members to understand each component need to be achieved. This will certainly affect the level of participation and trust of members towards the group. Purnomo et al (2016) stated that the overall involvement of the community in the empowerment program will foster ownership and responsibility for the programs. As well as improve community participation in development. Farmer participation supports the achievement of agricultural development programs (Aref F, 2011). Participation can be defined as a process in which all parties can be involved in all development initiatives. Participatory development is a process that improve engagement of the community in all substantial decisions relating to their lives (Syahyuti, 2014). The function and role of institution is the ability to manage information, human resources, capital and material resources, and it is concern several functions: acquisition, arrangement, maintenance, mobilization, and conflict management (Anantanyu et al, 2009). Moreover, the farmer has opportunities to exchange of information, provide training, sharing resources, and also can achieve economies scale of the member.

KEP in Magelang Regency has provided information to members, so members can easily obtain information about the requirements of membership, how to receive capital and the development of KEP business through working planning, business planning and the results of KEP accountability. Such information can be obtained through gapoktan ' officers, cooperative managers or fellow members. Interacation between members and officers will enhance good relationships as well as elicit participation of members within the cooperative. 
Management of human resources referred to is the selection of officers and managers in the institution. The selection of managers has been in accordance with the rule of its organization. Members of the cooperative know the way and the process of selection of officers and manager. Cooperative managers are considered to be able to organize resources in organization. However, for the provision of capital or loan has not been fully met, because it was imposible to cover all member. The existence of KEP provides assistance for members in obtaining capital for their farm business. Members also have no difficulty in obtaining capital, from collateral, services and fast process.

This condition is in line with the results of Anantanyu's research (2011). The institution of farmers is considered as the role of mobilizing human resources, put the farmers as object of development program. However, the capital and material resources are still limited because of the availability of physical facilities, lack of human resources, lack of access in technology. It need collaboration to improve farmers' ability in faming system.

Group innovativeness is measured by the role and function of leadership within the institution; division of member roles; cooperative action among members; availability of funding sources (Anantanyu et al, 2009). The Chairman of KEP in Magelang Regency gives attention to the rights and obligations in accordance with the position and duties for each employee and member. The chairman is also able to give authority in accordance with their position. The head of farmer'group had responsibility improve farmer' opportunity to talk and had access in decision making in organization. Gapoktan can be developed into KEP with legal status in form of cooperative hence, it can be said that the role of the head of Gapokatan is important. Member's interest in the organization was indicated by the participation of members in every activities undertaken by KEP.

One of the requirements of the organization is leadership, improve participation of the members in decision making and organizational activities, organizational capacity to provide benefits and services to members. Leadership is one indicator in assessing organizational performance. Good organizational performance is when all parts of the organization work properly, effectively, and efficiently, to achieve the objective (Syahyuti, 2011). Member awareness, cohesiveness, truust, and cooperation among member of organization are indicators of group sustainability. Members of KEP have the obligation to pay membership fee. Each member of KEP has the right to access for the loan, while the obligation is to pay the interest.

Trust among member of KEP can be seen from transparent and accountable of financial report. Members told that KEP managers can help them to improve their capital through access to loan. Many Gapoktan in Magelang regency had ability to make network with some institutions especially on the process marketing system. The Farmer's group have better marketing capacity compared to individual marketing, so they can reduce operating costs and earn higher income (Yang and Zimin, 2012). According to Mutiara, et al (2012) one of the institutional development strategy is through the improvement of farmers financing management capability by applying the principle of accountability as part of transparent business management, enhancing the ability to develop innovative and productive business activities through the utilization of technology resources and information, and develop partnerships with various parties. Members told that the existence of KEP can be continued and sustain through KEP, members can easily access their capital. These things certainly increase the participation of members in KEP. The participation of farmers in the institution affects the effect of farmer institutions (Anantanyu, 2009). The higher the participation of farmers in groups, the higher the effect of farmer's institutions. Community participation is believed to strengthen the capacity of local institutions. With participation, the farmer group can optain several benefits, such as: management skills, independence, trust, transparency, accountability, and access to resources (Anantanyu, 2009).

\section{CONCLUSION}

The effect of KEP has a positive effect on the empowerment activities in Magelang Regency. If the effect of KEP increases, then farmer's empowerment activities will be 
increased. The effectiveness of KEP still needs to be improved to increase the empowerment activities and income of farmers through provide more trainings in the farmer' group. The transformation of farmer institutions, both poktan and gapoktan in Central Java into Farmers Economy Institution is needed to be increased as well as the independence of the farmer institutions. It need to improve the role of extension workers in improving the institutional capacity of farmers as well as to supervise the farmers in decision making to improve their farm size and improve the farmer' welfare.

\section{REFERENCES}

1. Anantanyu Sapja, Sumardjo, M. Slamet, dan P. Tjitropranoto. 2009. Factors Affecting Farmer Institutional Effectiveness (Case in Central Java Province). Extension Journal 5(1): 81 - 91.

2. Aref Farshid. 2011. Farmers' Participation In Agricultural Development: The Case Of Fars Province, Iran. Indian Journal of Science and Technology 4 (2): 155 - 158.

3. Desiana, $\mathrm{N}$ and Atik A. 2017. Improving Income through Farmers' Group Empowerment Strategy. The Asian Journal of Technology Management 10 (1): 41-47.

4. Haryono, S dan P. Wardoyo. 2012. Structural Equation Modeling for Management Research Using AMOS 18.00. PT. Intermedia Personalia Utama. Bekasi.

5. Ministry of Agriculture. 2016. Guidelines for the Development and Development of Farmer Economic Institutions in 2016. Center for Agricultural Counseling of the Agricultural Human Resource Extension and Development Agency of the Ministry of Agriculture. Jakarta.

6. Mardikanto, T. 2009. Extension of Agricultural Development. Sebelas Maret University Press, Surakarta.

7. Purnomo, WE, D. Wahyuni, W. Paramita. 2016. The Village People Empowerment To Increase Social Welfare. Prosiding The Third International Conference on Law, Business and Governance (Icon-LBG 2016). Bandar Lampung University (UBL) Faculty of Law, Faculty of Economics and Faculty of Social Science. Page $45-49$.

8. Syahyuti. 2011. Difficult Easy to Organize Farmers: Study of Theory and Practice of Sociology of Institutions and Organizations. IPB Press. Bogor.

9. Yang, D and Zimin L. 2012. Study On The Chinese Farmer Cooperative Economy Organizations And Agricultural Specialization. AGRIC. ECON. - CZECH, 58, 2012 (3): 135-146. 